\title{
State regulation of logistics processes in accordance with the concept of sustainable development based on digital technologies
}

\author{
Tsenina Tatiana Tikhonovna \\ Saint-Petersburg State \\ University of Economics \\ Saint-Petersburg \\ Russian Federation \\ cakie@yandex.ru
}

\author{
Tsenina Ekaterina \\ Vladimirovna \\ Plekhanov Russian \\ University of Economics \\ Moscow, \\ Russian Federation \\ tsenina.t@yandex.ru
}

\author{
Tsou Tun \\ Saint-Petersburg State \\ University of Economics \\ Saint-Petersburg \\ Russian Federation \\ tszou.tun@yandex.ru
}

\begin{abstract}
The purpose of the research presented in this article is to develop scientific, methodological and applied aspects of improving the state regulation of logistics processes in the framework of Russian-Chinese trade cooperation from the perspective of the concept of sustainable development. As a result of the conducted desk research, the authors formalized the main tools of state regulation aimed at reducing the negative impact of logistics processes on indicators that reflect the effectiveness of the implementation of the concept of sustainable development. The statistical analysis of the indicators of investments in the regulation of the consequences of environmental pollution (China) and indicators of the volume of traffic by the main modes of transport (source of information - statistical aggregator Quandl, period - 2000-2016) allowed to form economic and mathematical tools for assessing the current level of indicators characterizing the environmental damage from logistics processes in the supply chains within the Russian-Chinese trade cooperation; to confirm the hypothesis that the logistics processes arising in the framework of trade cooperation between Russia and China, have a very negative, steadily increasing impact on the environment, which requires the adoption of measures of state regulation of these processes; and to determine that the greatest impact on the increase in investment in the regulation of the consequences of environmental pollution has an increase in freight traffic of road transport. According to the results of the study, a system of indicators of logistics processes was formed, which quantitatively characterize the effectiveness of the implementation of the concept of sustainable development in the framework of Russian-Chinese trade cooperation; it was formalized conditionally typical supply chain in the framework of Russian-Chinese trade cooperation with distinguishing sustainable logistics processes; the main indicators of sustainability of the logistics process were justified; a system of recommendations for improving the system of state regulation of logistics processes in the framework of RussianChinese trade cooperation from the position of reducing environmental damage is also proposed. This system of recommendations was tested on a typical example (for a period of 3 years) based on the use of digital technologies in order to obtain an information basis for balancing the market within the framework of the ratio of economic efficiency and sustainability of logistics processes and giving the system a cyclic character.
\end{abstract}

Keywords - the concept of sustainable development, sustainable logistics, logistics processes, state regulation of logistics processes, Russian-Chinese trade cooperation, digital technology in the regulation of logistics processes

\section{INTRODUCTION}

The concept of "sustainable development" became widespread in the 80 s of the 20th century, after the publication of the UN report "Our Common Future". To ensure the implementation of the concept of sustainable development at the macro level, it is necessary to refine the activities of all subsystems of the organization at the micro level, which requires the development of new technologies and methods of doing business, improving the quality of end results and the introduction of new, more effective management methods. Currently, the scientific community is increasingly discussing the impact of logistics as a factor of sustainable development in the economic, social and environmental spheres of society. The integration of the concept of sustainable development into the logistics processes of modern enterprises can reduce the negative impact that companies have on the ecosystem, reduce the burden on the environment and reduce costs throughout the supply chain. At the same time in the logistics subsystem of integrated solutions aimed at solving this problem, at the moment almost not formed. Furthermore, this process is characterized by the following contradiction: the costs of implementing sustainable logistics solutions should be borne by enterprises, and the effects are expected at the level of the macro environment as a whole.

The growing role of environmental factors in the management of logistics activities of the enterprise has caused the emergence of scientific and practical use of such terms as "green logistics", "environmental logistics", "sustainable logistics" [1, 2, 3, 4, 5]. The authors give the following definition of the term "sustainable logistics": it is a process of coordination of different types of flows and resources at all stages of the supply chain, the main purpose of which is to meet the needs of all stakeholders of the logistics system while minimizing the negative impact on the environment and achieving a stable balance between the environmental, economic and social objectives of the logistics system. 
In the works of a number of Russian and foreign scientists and specialists are considered in detail the theoretical and methodological aspects of sustainable logistics as a part of the business strategy of the company [6, 7], environmental logistics as a key factor in sustainable development $[8,9]$, approaches to the management of green supply chains $[10,11$, $12,13,14]$, as well as various examples of logistics activities in the framework of the concept of sustainable development [15, $16,17]$. However, the majority of scientific publications do not study the peculiarities of the organization and regulation of sustainable logistics processes, do not conduct a comprehensive analysis of the logistics problems of the concept of sustainable development of trade cooperation at the state level, insufficiently elaborated specific aspects and methodological features of the state regulation of logistics processes, taking into account the specifics of the implementation of the concept of sustainable development in the logistics activities of companies in certain markets.

Generally, despite the fact that the positive effect of the transition to the concept of sustainable logistics is obvious and extremely necessary, in the practice of enterprises, this transition causes some difficulties. Firstly, the reason for this is that the existing tools of sustainable logistics are fragmented, which is why the relevant measures are not implemented systematically enough, they often have a contradictory nature, because of the differences in their vector, the total effectiveness of reducing the harmful effects of logistics processes on the environment is often low. Secondly, the management of companies does not see a direct economic benefit from the implementation of sustainable logistics activities, but the costs are very high. One of the ways to solve this problem, the authors see the development of a system of measures of state support and state regulation of logistics processes, aimed at increasing the quantitative indicators of sustainability of the logistics subsystem both at the micro and macro level, which will form a more balanced program to improve environmental friendliness and efficiency of logistics systems.

Analysis of the studies shows a surge of interest in the subject of green logistics activities in 2014-2016 in China, as well as countries with high population density $[8,12,18,19]$. However, there is a low social sensitivity to "green" logistics and supply chains, the need to draw attention to the problem at the state level. A possible increase in social susceptibility is seen in a change in the production paradigm, where sustainability is no longer seen in terms of additional inefficient costs, but as a potential source of competitive advantage for companies [20]. Verstrepenetal [14] suggest that it is necessary to create the right supply chain structure to minimize system-wide cost by planning the movement of goods within the supply chain. Salema, Povoaand Novais [21] developed a conceptual model of manufacturing locations, distribution centers and disassembly centers for effective and efficient reverse logistics network with the aim of reducing the amount of waste and re-use of manufacturing resources. Fleischmann, Beullens, Bloemhof-Ruwaard, Wassenhove [11] proposed a model of the location of the re-production centers, as well as storage of the optimal amount of recovered products and used elements.
Based on the analysis of the literature, the authors formalized the main tools of state regulation aimed at reducing the negative impact of logistics processes on indicators that reflect the effectiveness of the implementation of the concept of sustainable development (refer to Table 1).

TABLE I. The Main Instruments Of State Regulation Aimed To REDUCE THE NEgATIVE IMPACT OF LOGISTIC PROCESSES ON PERFORMANCE, REFLECTING THE EFFECTIVENESS OF THE IMPLEMENTATION OF THE CONCEPT OF SUSTAINABLE DEVELOPMENT

\begin{tabular}{|l|l|l|}
\hline $\begin{array}{c}\text { Environmental } \\
\text { regulatory } \\
\text { instruments }\end{array}$ & \multicolumn{1}{|c|}{$\begin{array}{c}\text { Economic } \\
\text { regulatory } \\
\text { instruments }\end{array}$} & $\begin{array}{c}\text { Infrastrucutre } \\
\text { regulatory } \\
\text { instruments }\end{array}$ \\
\hline Emission standards & Emission taxes & Physical infrastructure \\
$\begin{array}{l}\text { Fuel efficiency } \\
\text { standards }\end{array}$ & Carbon trading & $\begin{array}{l}\text { Suboptimal } \\
\text { management of } \\
\text { infrastructure }\end{array}$ \\
$\begin{array}{l}\text { Restriction of } \\
\text { access of vehicles }\end{array}$ & Vehicle taxes \\
$\begin{array}{l}\text { Low-emission } \\
\text { zones }\end{array}$ & $\begin{array}{l}\text { Financial support } \\
\text { for R\&D }\end{array}$ & Removing market \\
Speed limit & $\begin{array}{l}\text { Promoting green } \\
\text { investments }\end{array}$ & \\
\hline
\end{tabular}

The subject of further research is the analysis of the impact of carriage by different modes of transport on the sustainable development of the region (on the example of the people's Republic of China) in the framework of trade cooperation between Russia and China.

The main objectives of the research presented by the authors in this article can be set as follows::

- to substantiate the need to take into account the negative impact on the environment in the management of logistics processes in the framework of Russian-Chinese trade cooperation;

- to form tools for assessing the current level of indicators characterizing the environmental damage from the logistics processes in the supply chains in the framework of the Russian-Chinese trade cooperation;

- to develop tools and a system of recommendations for improving the system of state regulation of logistics processes in the framework of Russian-Chinese trade cooperation from the standpoint of reducing environmental damage.

The main hypothesis of the study can be formulated as follows: logistics processes arising within the framework of trade cooperation between Russia and China, have an extremely negative, steadily increasing impact on the environment, which requires the adoption of measures of state regulation of these processes.

\section{MATERIALS AND METHODS}

The target indicator of sustainable development in this case is investment in the treatment of environmental pollution. Possible regressors, reflecting the impact of the transportation 
process on the environmental situation in the region, are the volume of cargo transportation. Freight traffic can also be differentiated according to a variety of classification criteria. For the purposes of this study, the mode of transport was chosen as a classifier: road transport, rail transport, water transport and air transport. The conceptual model is shown in Fig. 1.

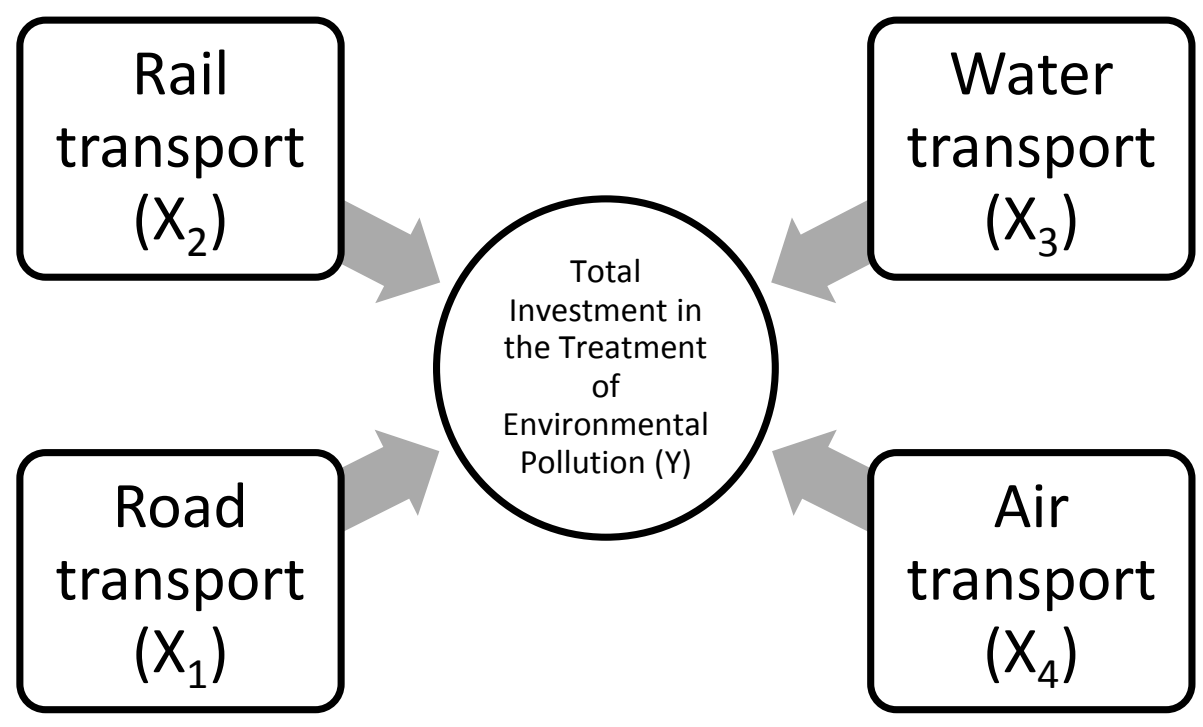

Fig. 1. Conceptual model of the study

Statistical information was taken for the period of 16 years (from 2000 to 2016), the source was the statistical aggregator Quandl. Using the tools of multiple linear regression, the following model was obtained:

$$
\begin{array}{r}
Y=-1024.65+0.086 \times X_{1}+0.035 \times X_{2} \\
+0.021 \times X_{3}+10.767 \times X_{4}
\end{array}
$$

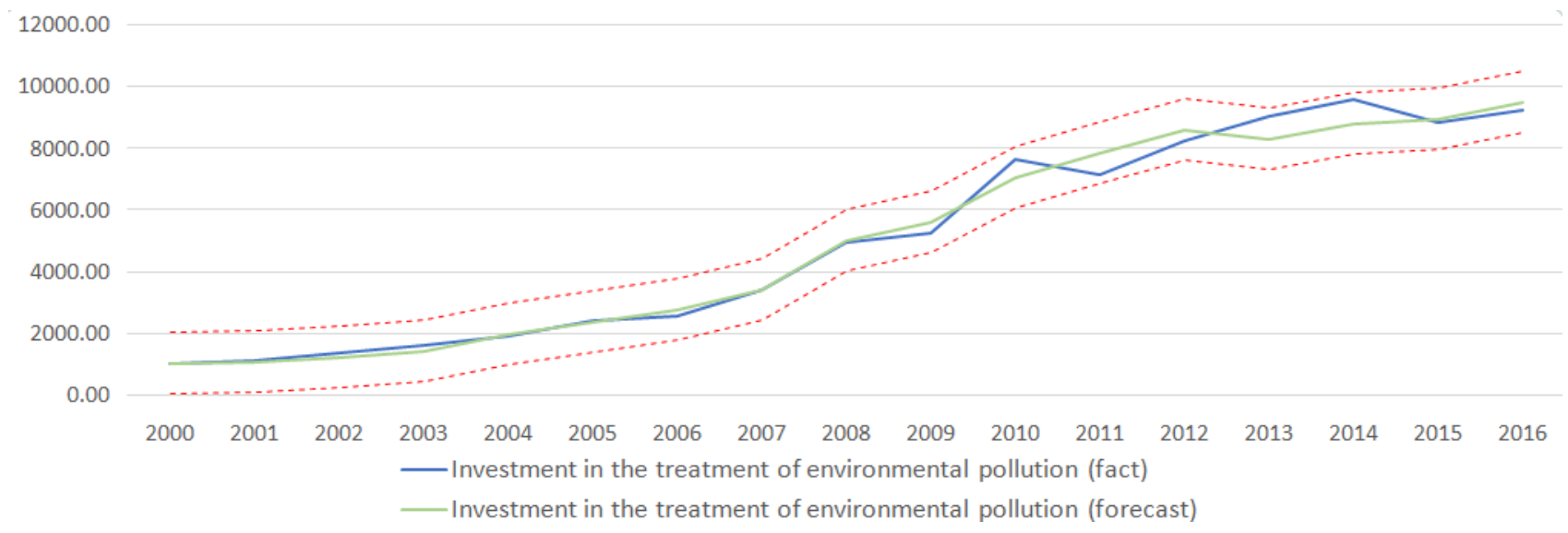

Fig. 2. Quality of approximation $\mathrm{Y}(\mathrm{y}-$ axis - million USD) 
There are no significant structural breaks and structural shifts in the graph, which indicates the high quality of the model. The vector of influence of regressors on the dependent indicator is logically justified. In this case, the strength of the influence of the selected regressors varies significantly. Fig. 3 shows the standardized regression coefficients of the model (1).

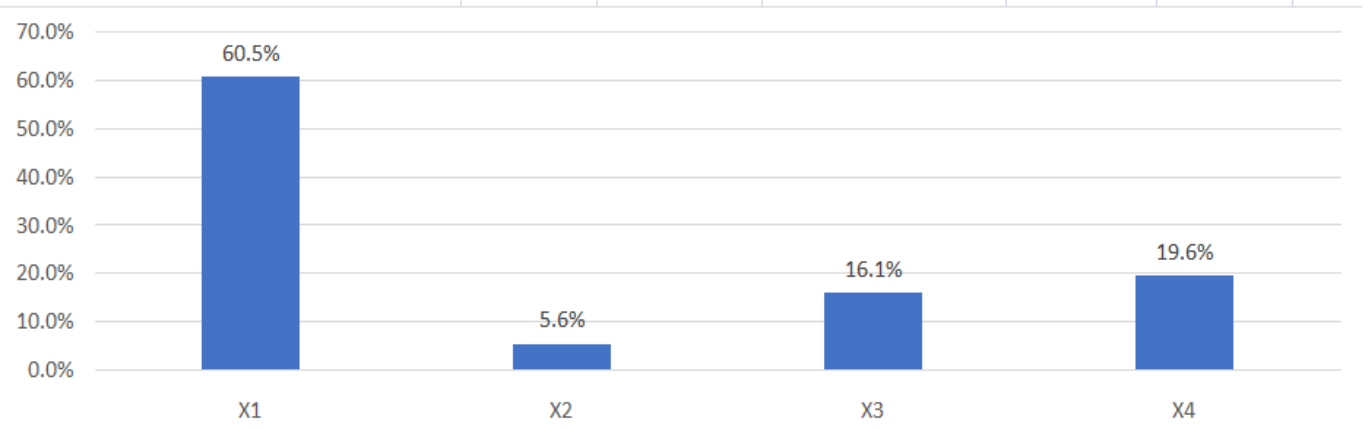

Fig. 3. Standardized regression coefficients of model (1)

As it is illustrated in Fig. 3, the greatest influence on the increment of investment in treating the consequences of environmental pollution renders the increase of freight traffic of road transport. The augmentation of air and water freight traffic has a much smaller impact. The most environmentally friendly (within the framework of the methodology of this study) is railway transport. ARIMA models $(2,1,2)$ were developed to predict future values of these indicators. These models were aggregated into a system of equations (2).

$$
\left\{\begin{aligned}
d X_{1_{n}}=4353.89 & +1.626 \times d X_{1_{n-1}}-0.865 \\
\times & d X_{1_{n-2}}+1.952 \times C C_{d X_{1_{n-1}}} \\
- & 0.996 \times C C_{d X_{1_{n-2}}} \\
d X_{2_{n}}=712.35+ & 0.436 \times d X_{2_{n-1}}-0.023 \\
\times & d X_{2_{n-2}}-0.382 \times C C_{d X_{2_{n-1}}} \\
+ & 0.326 \times C C_{d X_{2_{n-2}}} \\
d X_{3_{n}}=4786.69+ & 0.279 \times d X_{3_{n-1}}-0.237 \\
\times & d X_{3_{n-2}}+1.049 \times C C_{d X_{3_{n-1}}} \\
- & 0.87 \times C C_{d X_{3_{n-2}}} \\
d X_{2_{n}}=11.533+ & 0.011 \times d X_{4_{n-1}}-0.192 \\
\times & d X_{4_{n-2}}+0.559 \times C C_{d X_{4_{n-1}}} \\
+ & 0.427 \times C C_{d X_{4_{n-2}}}
\end{aligned}\right.
$$

The results of forecasting the studied indicators until 2022 are presented in figures $4-7$.

In accordance with the formed models of forecasting, for each of the studied indicators there is a steady growth. The results obtained make it possible to predict changes in $\mathrm{Y}$ up to 2022 (see Fig. 8). 


\section{Freight traffic of road transport}

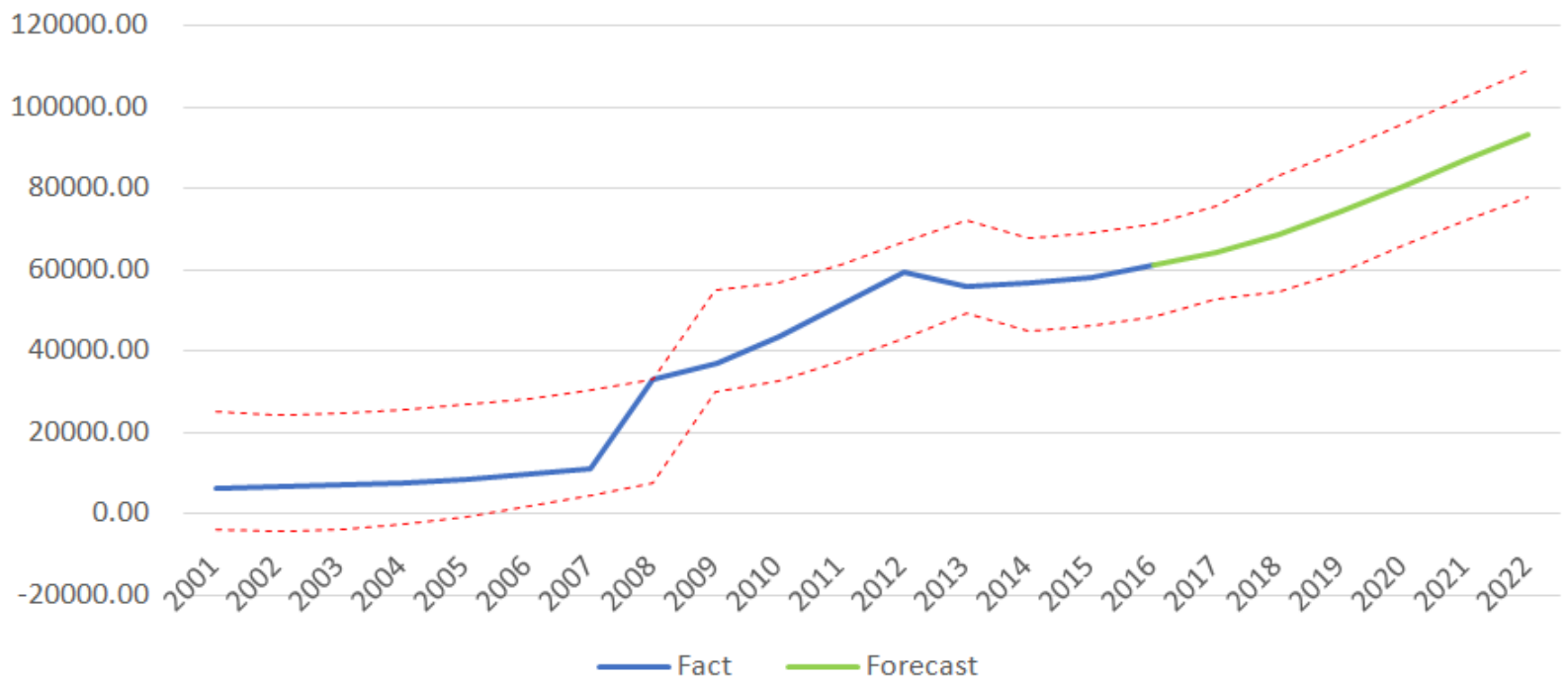

Fig. 4. Forecast volume of freight traffic by road transport (y - axis - thousand dollars)

\section{Freight traffic by rail}

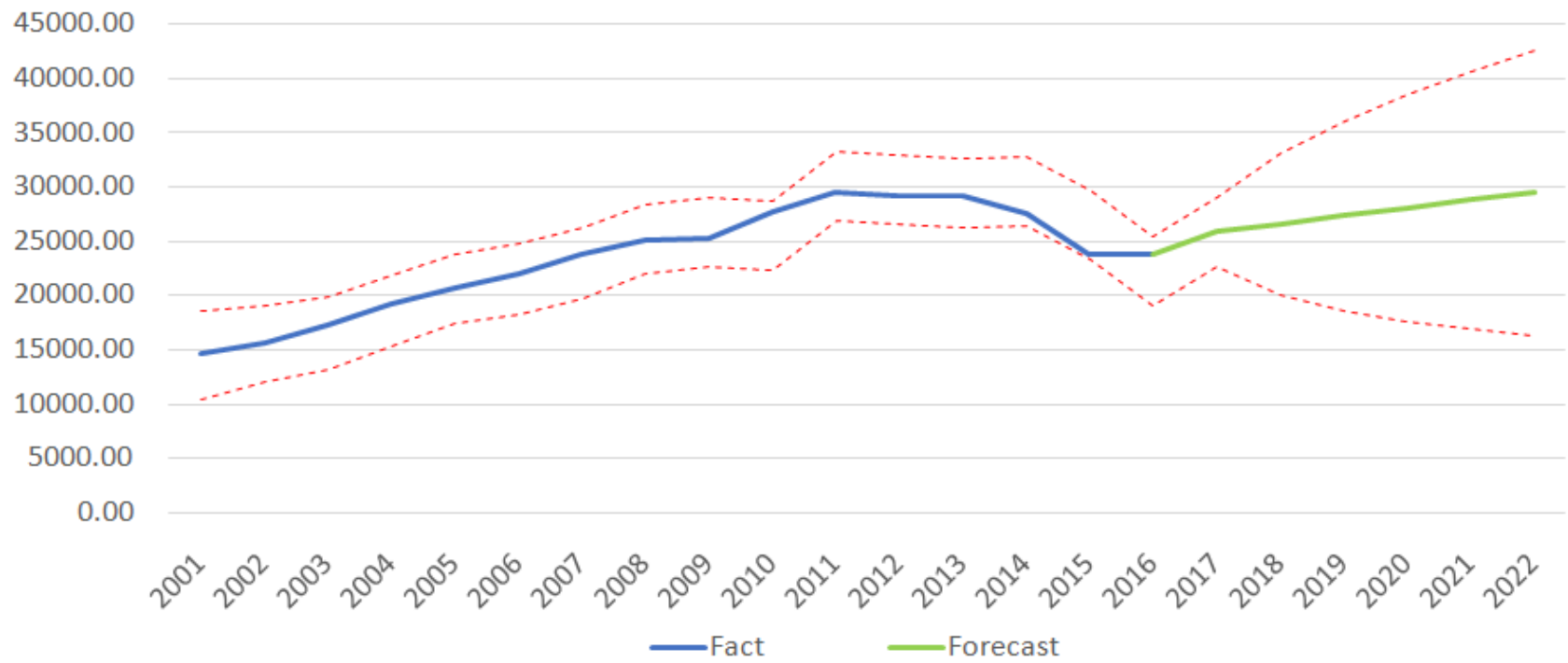

Fig. 5. Forecast volume of freight traffic by rail (y - axis - thousand dollars) 


\section{Freight traffic by water transport}

160000.00

140000.00

120000.00

100000.00

80000.00

60000.00

40000.00

20000.00

0.00

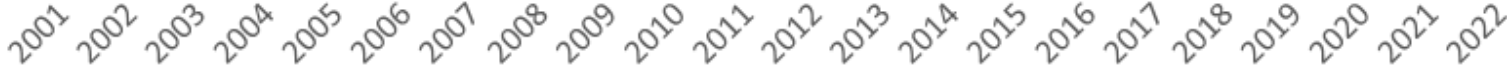

$$
\begin{aligned}
& \text { Fact } \quad \text { Forecast }
\end{aligned}
$$

Fig. 6. Forecast volume of freight traffic by water transport ( $\mathrm{y}$ - axis - thousand dollars)

Freight traffic by air transport

350.00

300.00

250.00

200.00

150.00

100.00

50.00

0.00

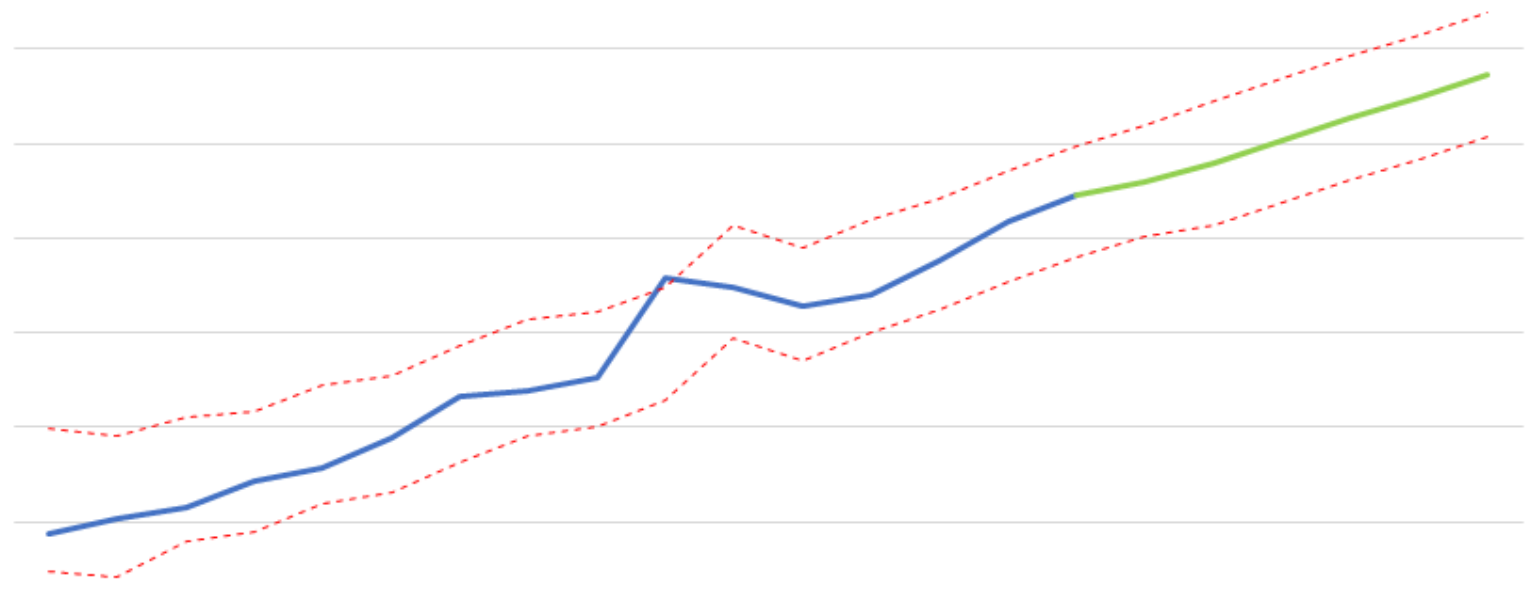

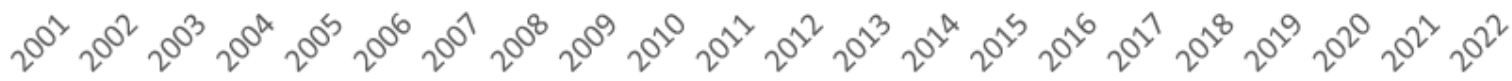

$$
\begin{aligned}
& \text {-Fact } \quad \text { Forecast }
\end{aligned}
$$

Fig. 7. Forecast volume of freight traffic by air transport (y - axis - thousand dollars) 


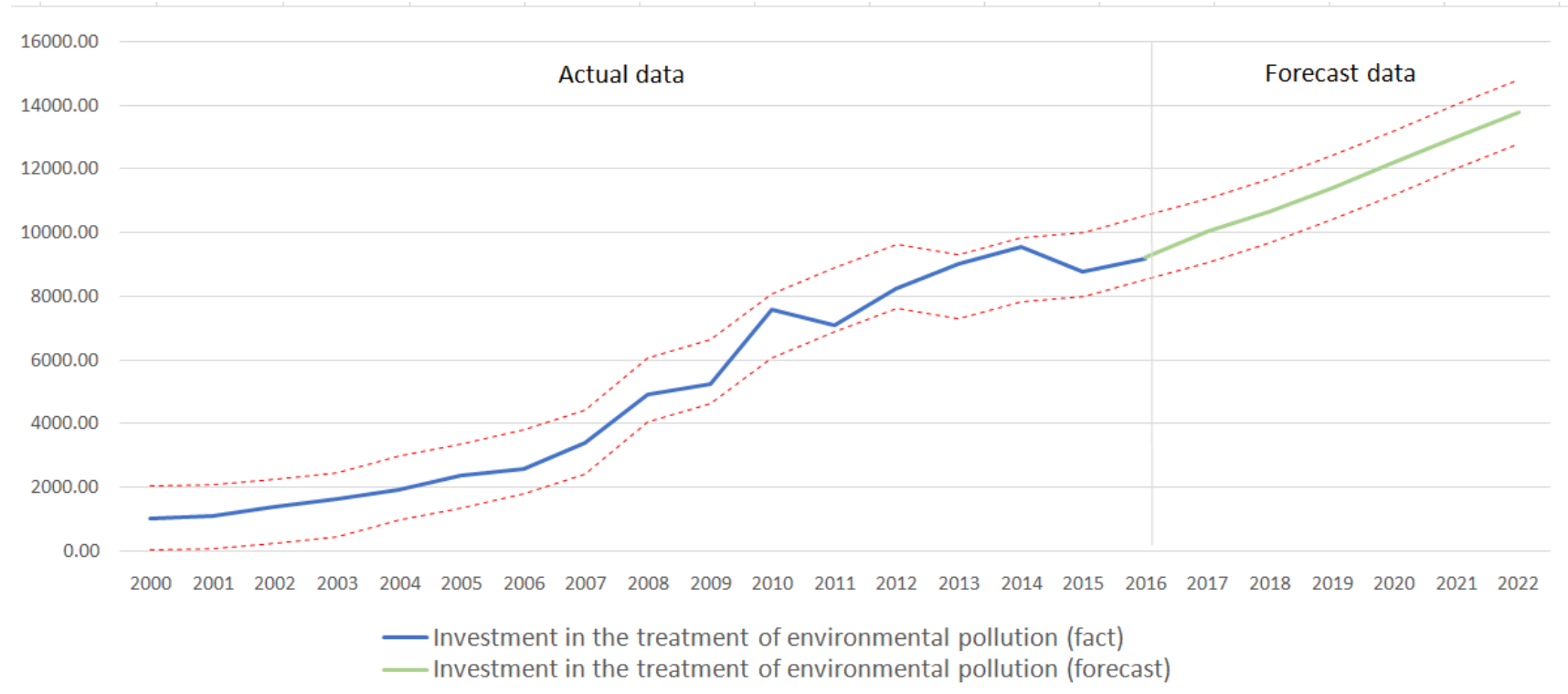

Fig. 8. Forecast of investments in the treatment of environmental pollution $(y-a x i s-$ thousand dollars $)$

As can be seen in fig. 8, investment in the treatment of environmental pollution will increase steadily until 2022 . This fact is a consequence of the augmentation in freight turnover in the main directions of transportation, in particular, the rapid growth of freight traffic on roads.

Consequently, the hypothesis that the logistics processes arising within the framework of trade cooperation between Russia and China have an extremely negative, steadily increasing impact on the environment is confirmed, which requires the adoption of measures of state regulation of these processes

\section{RESULTS}

According to the results of the study, the following approaches to solving the problems of trade cooperation between Russia and China concerning sustainable logistics can be identified:

- selection of suppliers of raw materials according to the criterion of maximum reduction of production waste, as well as elimination of losses from discard;

- reduction of inventories due to improvement of the system of planning and rationing of the expense;

- elimination of intermediate warehousing and transshipment, which will reduce the need for warehouse space;

- reduction of empty mileage of vehicles;

- consolidation of consignments in logistic channels corresponding to more "eco-friendly" modes of transport (rail, water, air).

Despite the fact that in the past for the prediction and calculation of total logistics costs in supply chains has been developed a clear methodology, it is necessary to consider also the "green factor" in supply chain management. It is necessary to develop a system of criteria for assessing the impact of logistics processes within the Russian-Chinese market on indicators that quantitatively characterize the effectiveness of the implementation of the concept of sustainable development (see table 2). The control variables in this case will be the number of workers and the creation of additional jobs in developing countries.

TABLE II. THE MaIN IndicAtors Of Logistics Processes That QuantiTATIVEly Characterize THE PERFoRMANCE Of THE IMPLEMENTATION OF THE CONCEPT OF SUSTAINABLE DEVELOPMENT IN THE FRAMEWORK OF THE RUSSIAN-CHINESE TRADE COOPERATION

\begin{tabular}{|c|c|}
\hline "Traditional" indicators & $\begin{array}{c}\text { Indicators for the } \\
\text { implementation of the concept } \\
\text { of sustainable development }\end{array}$ \\
\hline $\begin{array}{l}\text { - Quantity of transported goods } \\
(\rightarrow \max )\end{array}$ & - Emissions CO2 $(\rightarrow \min )$ \\
\hline $\begin{array}{l}\text { - The cost of transportation of } \\
\text { goods }(\rightarrow \text { min })\end{array}$ & 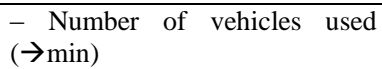 \\
\hline $\begin{array}{l}\text { - Time for cargo transportation } \\
(\rightarrow \text { min })\end{array}$ & $\begin{array}{l}\text { - The total mileage of vehicles } \\
(\rightarrow \min )\end{array}$ \\
\hline \multirow[t]{8}{*}{$\begin{array}{l}\text { Costs related to the } \\
\text { organization of distribution } \\
\text { centers }(\rightarrow \text { min })\end{array}$} & $\begin{array}{l}-\quad \text { Number of warehouses } \\
(\rightarrow \text { min })\end{array}$ \\
\hline & - Structure of fleet of vehicles \\
\hline & - Fuel consumption $(\rightarrow \min )$ \\
\hline & $\begin{array}{l}\text { - Structure of the use of different } \\
\text { fuels }\end{array}$ \\
\hline & $\begin{array}{l}\text { - Number of vehicles not used } \\
\text { for as intended }(\rightarrow \min )\end{array}$ \\
\hline & - Inventory level \\
\hline & $\begin{array}{l}\text { - Weight, volume and quantity } \\
\text { of packaging material used } \\
(\rightarrow \text { min })\end{array}$ \\
\hline & $\begin{array}{l}\text { - Raw materials and packaging } \\
\text { that cannot be recycled or safely }\end{array}$ \\
\hline
\end{tabular}




\begin{tabular}{|l|l|}
\hline & disposed $(\rightarrow \min )$ \\
\hline & $\begin{array}{l}- \text { Empty mileage of vehicles } \\
(\rightarrow \min )\end{array}$ \\
\hline & - Reuse of materials \\
\hline
\end{tabular}

\section{DISCUSSION}

In the framework of the logistics systems of different levels, many kinds of logistic processes can be identified. However, not all of them are manageable in terms of the concept of sustainable development. It is stipulated by the fact that the category of sustainability (in the considered connotation) is inherent only for the external logistics environment, while the impact of internal logistics processes on the environment can be neglected. Thus, it is possible to distinguish two types of logistics processes from the perspective of managing their sustainability:

1. Sustainable logistics processes (SLP). SLP refer to logistics processes that have a significant impact on the achievement of environmental goals within the concept of sustainable development;

2. Neutral logistics processes (NLP). NLP refer to logistics processes that do not have a significant impact on the achievement of environmental goals within the concept of sustainable development.

For the purposes of identification of SLP it is necessary to formalize conditional typical supply chain with emphasizing of SLP (see Fig. 9) 


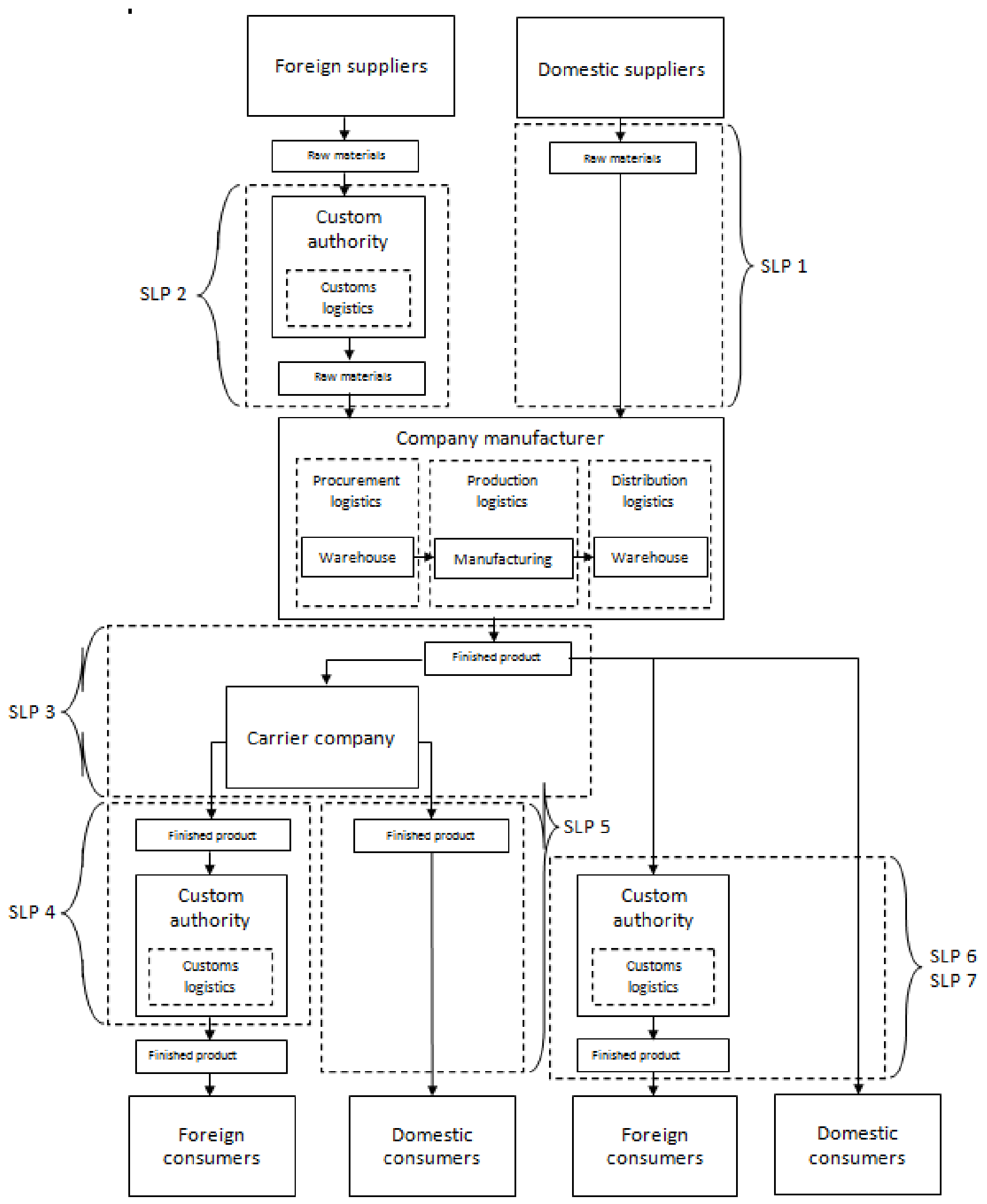

Fig. 9. Conditionally typical supply chain in the framework of trade cooperation between Russia and China with emphasizing of sustainable logistics processes (SLP) 
For the purpose of improving sustainability of logistics processes, in is necessary to create a system of incentives that makes it disadvantageous for the subjects of the logistics system to deviate respective indicators from their conditional standard values. In order to build this system, it is necessary to determine the possible directions of influence on the controlled entities of the logistics system by the managing entities. These directions of influence are based on the nature of the corresponding indicator. First of all, let us consider indicator $\mathrm{I}_{1}$ (the increase in the share of road freight traffic due to the increase in the distance traveled by road freight transport in the reporting year), since according to the results of the empirical study, it was found that the greatest impact on the increase in investment in the treatment of environmental pollution has an increase in freight traffic of road transport. The authors have formulated the following key areas of influence of the state:

1. The increase in the cost of fuel with an increase in this indicator. This direction can be implemented through the introduction of an additional tax, or the introduction of a floating scale tax "on the environment" which is paid by the owners of cars with diesel engines;

2. Introduction of a specialized tax with a floating scale for owners of freight vehicles, the calculation base of which is the length of the path traveled by the vehicle for the year;

3. Limiting the use of road transport as part of the obligations under government contracts;

4. Introduction of additional customs duties for goods transported by road. The value of these payments should also be variable;

5. Increased investment in railway construction and maintenance.

It should be noted that these directions of influence are quite universal, and can be applied with a certain degree of adjustment to subsequent indicators. Let us consider a set of deterioration indicators $\mathrm{I}_{2}$ (the level of deterioration of railway vehicles); $\mathrm{I}_{3}$ (the level of deterioration of motor vehicles); $\mathrm{I}_{4}$ (the level of deterioration of railway transport containers); $\mathrm{I}_{5}$ (the level of deterioration of motor vehicles containers); $\mathrm{I}_{7}$ (the level of deterioration of water transport). The authors have formulated the following key areas of influence of the state:

1. Introduction of a floating scale of transport tax for lorries, depending on the degree of deterioration of the object of taxation. It should be noted that the increment of these indicators can also have an impact on the increase in the corresponding transport tax as a whole;

2. Introduction of state subsidies for the renewal of the fleet, the amount of which depends directly on the value of the increment of the relevant indicators;

3. Introduction of special customs duties on freight vehicles, the value of which is functionally dependent on the year of production of rolling stock and transport containers.
No less important from the point of view of the potential risk to the environment is the logistics of dangerous goods. Indicator $\mathrm{I}_{6}$ - increment of the volume of dangerous goods carried - has been introduced for the purpose of assessing the level of this risk. Its growth indicates an augmentation in the risk of damage to the environment. Therefore, it is possible to allocate the following directions of regulation of its increment:

1. Introduction of a special fee for the transportation of dangerous goods. The amount of this fee may vary with the change of $\mathrm{I}_{6}$;

2. Creation of a system of compulsory insurance of the process of transportation of dangerous goods. Tariffs may be set by the state and vary depending on the change $\mathrm{I}_{6}$.

The development of more ecological modes of transport is also significant, which was also determined by the results of the empirical study. The following indicators have been developed to study this dynamics: $I_{8}$ (increment of electric freight transport), $I_{9}$ (increase in the share of natural gas transport) and $I_{10}$ (increment of the share of transport complying with Euro-6 standards). The increment of each of the selected indicators has a positive impact on the sustainability of logistics processes. The authors have formulated the following main directions of their regulation:

1. Reduction of the transport tax as a whole for all freight transport, and separately for the selected types of vehicles;

2. State subsidies for the acquisition of a more ecological type of freight transport;

3. Reduction of customs duties on selected types of freight transport.

In conclusion, we should consider the retrospective dynamics of changes in the number of precedents of damage to the environment. Indicators $\mathrm{I}_{11}, \mathrm{I}_{12}, \mathrm{I}_{13}$ и $\mathrm{I}_{14}$ (the dynamics of the number of precedents of environmental damage in the framework of logistics processes to the biosphere, to water resources, to land resources, to forest resources, respectively) have been developed for these purposes. To reduce these indicators, the following directions can be proposed:

1. Improving the quality of highways;

2. Introduction of a specialized environmental fee, the amount of which varies depending on the size of these indicators;

3. Formation of a system of targeted compensation for environmental damage.

It should be noted that the above activities formulated by the authors are based on the legislation of China. They can be unified, but this may require significant changes in tax, customs and transport legislation. Selected activities can be converted into specific regulatory instruments:

- Change in the rate of transport tax on freight vehicles RTtfv). 
- Change in the rate of transport tax on cargo water transport- RTtcwt).

- Introduction of a single environmental fee for all carriers (EFt).

- Increasing investment in the upgrade of railway transport (IRT).

- Introduction of a special customs tariff for road freight transport (TTtfv).

The developed tools together represent a system of state regulation of logistics processes on the principles of the concept of sustainable development. The purpose of this system is to achieve an optimal level of stability of logistics processes within the framework of Russian-Chinese trade cooperation.

This system of state regulation will function most effectively if it is cyclical, which can be implemented only with the help of digital technologies, the use of which will help to balance the market within the framework of the ratio of economic efficiency and sustainability of logistics processes.

For the purpose of assessing the effectiveness of the developed system of state regulation, a test case was developed, within which 3 periods are considered:

1. Year $\mathrm{m}-1$ - during this period, the system has not yet been introduced, but it is integrated, the primary information basis is formed;

2. Year $m-$ during this period, the system begins to function and an information basis is forming. Regulatory instruments are assigned their basic values;

3. Year $m+1$ - during this period, the indicators for assessing the sustainability of logistics processes are determined and new values of regulatory instruments are formed based on the results.

In table 3 changes in the values of regulatory instruments are presented.

TABLE III. Change The VAlues Of Regulatory Tools

\begin{tabular}{|c|c|c|c|}
\hline № & $\begin{array}{c}\text { Regulatory } \\
\text { tool }\end{array}$ & Year $m+1$ & Year $m+2$ \\
\hline 1. & $\mathrm{RT}_{\mathrm{tfv}}^{\min }$ & $\begin{array}{l}16 \text { CNY per } 1 \text { ton } \\
\text { of vehicle own } \\
\text { weight }\end{array}$ & $\begin{array}{l}11.43 \mathrm{CNY} \text { per } 1 \\
\text { ton of vehicle own } \\
\text { weight }\end{array}$ \\
\hline 2. & $\mathrm{RT}_{\mathrm{tfv}}^{\max }$ & $\begin{array}{l}120 \mathrm{CNY} \text { per } 1 \text { ton } \\
\text { of vehicle own } \\
\text { weight }\end{array}$ & $\begin{array}{l}85.75 \mathrm{CNY} \text { per } 1 \\
\text { ton of vehicle own } \\
\text { weight }\end{array}$ \\
\hline 3. & $\mathrm{RT}_{\mathrm{tcwt}}^{\min }$ & $\begin{array}{l}3 \mathrm{CNY} \text { pet } 1 \text { ton of } \\
\text { deadweight cargo } \\
\text { tonnage } \\
\text { tonnage) }\end{array}$ & $\begin{array}{l}3.29 \mathrm{CNY} \text { pet } 1 \text { ton } \\
\text { of deadweight } \\
\text { cargo tonnage (net } \\
\text { tonnage) }\end{array}$ \\
\hline 4. & $\mathrm{RT}_{\mathrm{tcwt}}^{\max }$ & $\begin{array}{l}\text { 6 CNY pet } 1 \text { ton of } \\
\text { deadweight } \\
\text { tonnage } \\
\text { tonnage) }\end{array}$ & $\begin{array}{l}6.58 \mathrm{CNY} \text { pet } 1 \text { ton } \\
\text { of deadweight } \\
\text { cargo tonnage (net } \\
\text { tonnage) }\end{array}$ \\
\hline 5. & $\mathrm{EF}_{\mathrm{t}}$ & $1 \%$ of revenue & $0,86 \%$ of revenue \\
\hline 6. & IRT & 15000000 USD & 15462725 USD \\
\hline
\end{tabular}

As can be seen, the use of digital technologies for obtaining an information basis makes it possible to balance the market and gives the system a cyclic character, which in turn allows to increase the economic efficiency of logistics processes in response to the increment of their stability. This system of state regulation, based on the collection of information using digital technologies, enables enterprises to manage their logistics processes in accordance with the concept of sustainable development.

\section{CONCLUSION}

Within the scope of this article, the authors justified the role of logistics in the concept of sustainable development; defined logistics issues due to the multidirectional nature of the enterprise goals at the micro level and the goals of the concept of sustainable development at the macro level; justified the need to take into account the negative impact on the environment in the management of logistics processes within the framework of Russian-Chinese trade cooperation; the tools for assessing the current level of indicators characterizing the environmental damage from the logistics processes in the supply chains in the framework of the Russian-Chinese trade cooperation have been developed; the main instruments of state regulation aimed at reducing environmental damage from logistics processes in supply chains within the framework of Russian-Chinese trade cooperation are formalized; the tools and system of recommendations for improving the system of state regulation of logistics processes in the framework of Russian-Chinese trade cooperation are developed from the perspective of reducing environmental damage, as well as their testing based on the use of digital technologies is done (obtaining an information basis for the purposes of balancing the market within the framework of the ratio of economic efficiency and sustainability of logistics processes and giving the system a cyclic character).

\section{REFERENCES}

[1] Ali S.S. Optimization approach in the management of "green" supply chains with feedback (on the example of an Indian company). Problems of nonlinear analysis in engineering systems, 2015, Vol.2 (44). No 21. pp. $121-146$.

[2] Gviliya N.A., Mikhaylova K.O. Logistics organization of transnational corporations in the current economic situation. Bulletin of Astrakhan state technical University. Scientific journal. Economy Series. 2016, Vol 1. pp. 100-106.

[3] Kapustina L.M. "Green" technologies in logistics. News of Ural State University of Economics. 2016, Vol. 2 (64). pp.114-122.

[4] Karpova N.P., Pilipovich E.D. Environmental logistics as the basis of the company's sustainable development strategy. Eurasian Union of scientists. 2016, Vol.2 (23). pp. $79-81$.

[5] Klumpp M. To green or not to green: a political, economic and social analysis for the past failure of green logistics. Sustainability, 2016, Vol. 8, iss. 5. pp. 1-22.

[6] Gviliya N.A., Tsenina E.V. Creation of key performance indicators system for managing company's procurement logistics and its suppliers. Problems of modern economy. Eurasian international scientific and analytical journal. 2017, Vol. 1 (61). pp.97-100. 
[7] Sakal P., Fidlerova Kh. Sustainable logistics strategy as part of business strategy. Problems of the territory development. 2013, Vol. 3 (65). pp. $25-30$.

[8] Omelchenko I.N., Aleksandrov A.A., Brom A.E., Belova O.V. Main directions of development of logistics in the twenty-first century: resource saving, energy and the environment // Humanitarian bulletin of the Bauman MSTU: electronic journal. 2013, Vol 10 (12).

[9] Konnikov E.A., Konnikova O.A. Trends of sustainable marketing in production and distribution. Bulletin of the managment faculty of St. Petersburg State Economic University. 2018, Vol.3. pp.410 - 416.

[10] Zaychenko I., Smirnova I., Borremans A.D. Digital transformation: The case of the application of drones in construction. MATEC Web of ConferencesVolume 193, 20 August 2018, Number 050662018
[11] Fleischmann M., Beullens P., Bloemhof-Ruwaard J.M., and Van Wassenhove L.N. (2001) The impact of product recovery on logistics network design. Production and operations Management, Vol. 10 (2), pp.156-173.

[12] Gromov V. Green Logistics in Russia (Review article). Russian Journal of Logistics and Transport Management. 2014, Vol. 1. No. 2. pp. 36-44.

[13] Scherbakov V., Smirnova E. Global supply chain imperatives. Journal of Applied Economic Sciences. 2018, Vol. 13. No 7(61). pp. 1888-1901.

[14] Verstrepen S., Cruijssen F., De Brito M.P., and Dullaert W. An exploratory analysis of reverse logistics in Flanders. European Journal of Transport and Infrastructure Research. 2007, Vol. 7(4), pp.301-316.

[15] Osintsev N.A., Rakhmangulov A.N., Baginova V.V. Innovations in the area of green logistics. World of transport. 2018, Vol. 16. No 2. pp. 196 $-211$.

[16] Tsenina E.V., Tsenina T.T. Identification of risks in international freight forwarding activities. Scientific and practical journal. Problems of risk analysis. 2016, Vol. 13. No 6. pp. 64-68

[17] Visser H. M., van Goor A.R. Logistics: Principles and Practice. 2nd edition. 's-Gravendeel, 2011, $452 \mathrm{p}$.

[18] Tsenina T.T. Changes in China's foreign trade with Russia. In the collected works: logistics and supply chain management. Collection of scientific papers. Saint-Petersburg, 2017. pp. 90-92.

[19] Tsou Tun Analysis of the impact of transport by different modes on the sustainable development of the region (on the example of the people's Republic of China). Economy and entrepreneurship. 2019, Vol.2. pp. 384 - 388.

[20] Lakshmimeera B.L., Palanisamy C. A conceptual framework on green supply chain management practices. Industrial Engineering Letters, 2013, Vol. 3, No.10, pp. 42-51.

[21] Salema M., P'ovoa A., and Novais A. A strategic and tactical model for closed- loop supply chains. OR spectrum. 2009, No 31(3). pp. 573-599. 